\title{
BENDING OF SAWN WOOD PRODUCTS OBTAINED FROM CONVENTIONAL SAWING AND PARALLEL TO GENERATRIX SAWING
}

\author{
Vladimir N. Glukhikh¹, Olga Yu. Khrabrova² \\ ${ }_{1}$ Saint Petersburg State University of Architecture and Civil Engineering, \\ Vtoraja Krasnoarmejskaja ul.4, St. Petersburg, 190005, Russia \\ VNGlukhikh@mail.ru \\ ${ }_{2}$ Saint-Petersburg State Forest Technical University, \\ Institutskiy per.5, St. Petersburg, 194021, Russia \\ olyah@inbox.ru
}

\begin{abstract} conventional sawing and sawing parallel to log generatrix.

\section{Keywords}

Bending, stiffness, elasticity modulus, stresses, strength.

\section{Introduction}

Wooden house construction becomes the object of great interest under the current economic conditions. Wood is considered as anisotropic material which properties could ten times differ one from another in terms of different structural directions (Ashkenazi, 1978; Glukhikh, 2007). Generation of wood structure as a center of equal strength facilitated improvement of mechanical and physical characteristics longitudinal to the fibers ten times greater than those transverse to the fibers. Ideally, the wood fibers in sawn wood products are to be parallel to the edges and sawn faces of sawn wood products and stocks. In this case the fibers are not cut off and bending, tensile and compaction strength values are at their maximum.
\end{abstract}

This paper considers bending of sawn wood products obtained from logs by conventional sawing and sawing parallel to generatrix. Issues related to strength and stiffness of sawn wood products sawn parallel to generatrix have not being studied yet, thus such issues are of practical and scientific interest. Earlier our investigation dealt with changes in tilting angle of wood fiber of sawn wood materials obtained from logs by

This concept is used for generating of mathematical models describing changes in elasticity modulus across the wood plank width which enables to foresee the wood plank bending strength and stiffness.

The proposed procedure allows for the evaluation of wood planks bending stresses occurred when various log sawing schemes were used. Wood planks bending value is calculated to cover the difference between stiffness of wood planks obtained at the implementation of both sawing schemes.

The investigation results are not only of scientific interest, but are also of practical interest in terms of construction and fabrication of laminated wood structures, wood structural panels etc.

In reality the tree trunk shape is not cylindrical, so the fibers are turned to be cut off which adversely affects wood products and stocks strength and stiffness.

Researchers and practitioners are continuously searching and developing schemes for log sawing aimed at the increase of volume output of sawn wood products at sawing, reduction of sawn wood products loss during further drying, increase of strength of structural sawn wood products used for building structures fabrication.

One of the up-to-date schemes for sawlog material cut-up is sawing parallel to generatrix. Experienced sawyers acknowledge obtaining of more wide sawn wood products when sawing parallel to generatrix (Fig.1). However, degradation in drying quality of such materials is not taken into account, as the core 
of the materials protrude to both sawn faces and at some areas along the length of wood plank the fibers are cut off under the angle twice greater than that of conventional cutting material.

It is obvious that when wood planks are located on the one side relative to the log axis, transverse and longitudinal distortion do not change their signs along the plank. This statement is proven by numerous investigations (Akishenkov, 1980; Kolenchuk, 1950; Lyulenko, 1967; Petrukhin, 1970, Skripal'shchikova, 1975; Sokolov, Glukhikh, 1971; I.

A. Strikha, 1974; Sukhova ,1958, etc.).

Our investigations (Glukhikh, Chernykh, 2013; Glukhikh, Zaripov, 2008) prove out that when drying, distortion of wood plank with end face located on various sides relative the log axis changes in terms of sign along the plank. The paper (Glukhikh, 2004) confirms that shrinkage stresses in the core of wood plank is more than 4 times higher than the same stresses in wood planks produced out of periphery zone. Considering this fact, one can consider double-sided log sawing parallel to generatrix more reasonable (Fig.2).

Issues related to strength and stiffness of such materials are not investigated, but they are of scientific and practical interest. Each new log sawing scheme as well as the procedure, effective output and other issues are to be explained in terms of strength and stiffness. This relates to sorting out of structural sawn wood products, fabrication of laminated wood structures, wooden structural panels, wooden and wooden-concrete bridges, etc.

We evaluated changes in tilting angle of wood fiber of sawn wood materials obtained from logs by conventional sawing and sawing parallel to log generatrix (Glukhikh, Khrabrova, Akopyan, 2013). This concept can be used to foresee the nature of changes in wood plank and their bending stiffness.

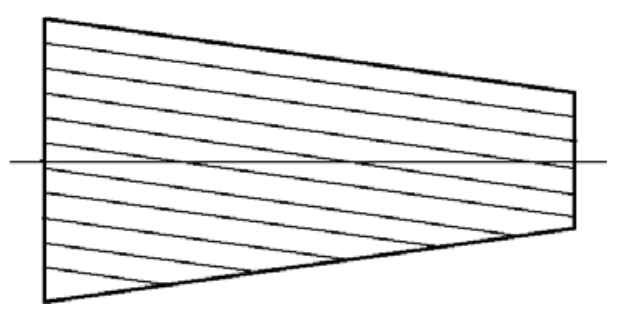

Fig.1 Single sided sawing of a log parallel to tapering

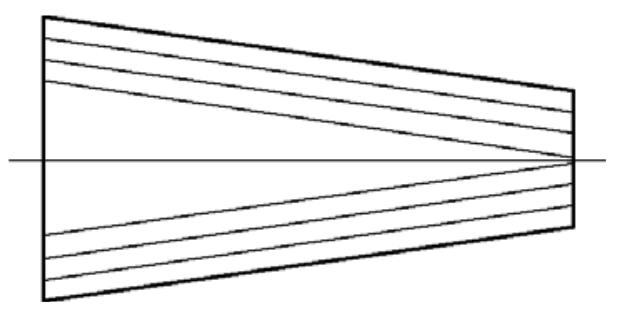

Fig.2 Double sided sawing of a log parallel to generatrix
2. Investigation of bending stresses in wood planks obtained by various log sawing schemes

Taking into account changes of wood fiber angles of tilting to three mutually perpendicular axis passing through sawn faces, end face, plank edge, the solution can be considered for a beam with changing modulus of elasticity.

The solution shall be found out for one of the simplest bar schemes (Fig.3).

The task is to be solved using the methods of theory for anisotropic body elasticity.

Hook's general law shall be used under the condition of small deformations:

$$
\begin{aligned}
& \varepsilon_{z}=\frac{\partial v}{\partial z}=\frac{\sigma_{z}}{E_{z}}-\mu_{y} \frac{\sigma_{y}}{E_{y}} \\
& \varepsilon_{y}=\frac{\partial \vartheta}{\partial y}=-\mu_{z} \frac{\sigma_{z}}{E_{z}}+\frac{\sigma_{y}}{E_{y}} \\
& Y_{z y}=\frac{\partial v}{\partial y}+\frac{\partial \vartheta}{\partial z}=\frac{1}{G} \tau_{z y}
\end{aligned}
$$

where $E_{z}, E_{y}, \mu_{z}, \mu_{y}, G$ are arbitrary functions of constant elasticity of wood as an anisotropy object,

$\mathrm{E}_{\mathrm{z}}, \mathrm{E}_{\mathrm{y}}$ - elasticity modulus;

$\mu_{\mathrm{z}}, \mu_{\mathrm{y}}-$ transverse deformation coefficients (Poisson's coefficient);

$\mathrm{G}$ - elasticity modulus of displacement.

Equilibrium equations are as follows:

$$
\begin{aligned}
& \frac{\partial \sigma_{\mathrm{z}}}{\partial \mathrm{z}}+\frac{\partial \tau_{\mathrm{zy}}}{\partial \mathrm{y}}=0 \\
& \frac{\partial \tau_{\mathrm{zy}}}{\partial \mathrm{z}}+\frac{\partial \sigma_{\mathrm{y}}}{\partial \mathrm{y}}=0
\end{aligned}
$$

Limiting condition values for this example:
a) $\mathrm{y}=0 ; \sigma_{\mathrm{y}}=0$
b) $\mathrm{y}=0 ; \tau_{\mathrm{zy}}=0$
c) $\mathrm{y}=\mathrm{b} ; \sigma_{\mathrm{y}}=0$
d) $\mathrm{y}=\mathrm{b} ; \tau_{\mathrm{zy}}=0$

Besides those four limiting conditions, the following equilibrium conditions are to be met
a) $\int_{0}^{b} \sigma_{z} d y=0$
b) $\int_{0}^{b} \sigma_{z} y d y=-P \frac{z}{h}$
c) $\int_{0}^{b} \tau_{z y} d y=-\frac{P}{h}$

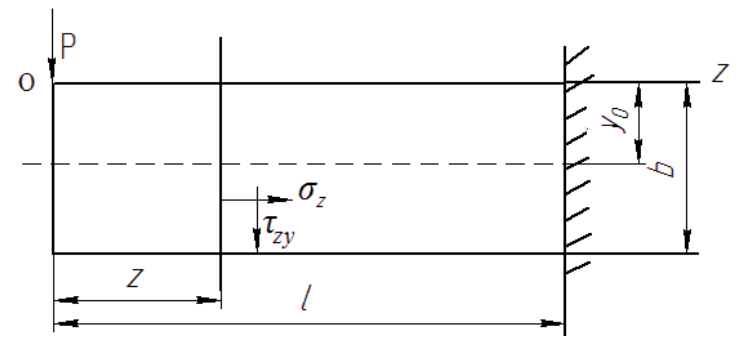

Fig.3. Scheme of an anisotropic beam 
where $\mathrm{h}$ is width of transverse section (in our case this is the plank thickness).

When solving the similarproblem, S.G. Lekhnitskiy (Lekhnitskiy, 1957) suggests that the nature of stresses distribution within such anisotropic beam is the same as that occurred at any other uniform beam, i.e.

$$
\sigma_{\mathrm{z}}=-\frac{\mathrm{Pz}}{\mathrm{h}} \mathrm{f}^{\prime}(\mathrm{y}), \tau_{\mathrm{zy}}=\frac{\mathrm{P}}{\mathrm{h}} \mathrm{f}(\mathrm{y})
$$

Suggesting validity of the second hypothesis on pure bending, on the basis of which the beam fibers do not apply pressure on each other at transverse bending thus subjecting to longitudinal tensile (compaction) deformation, i.e. $\sigma_{y}=0$.

Applying interrelations (5), Hook's general law (1), equilibrium equations (2), conditions (3) and (4), S.G. Lekhnitskiy found the following function of $f(y)$ (Lekhnitskiy, 1957):

$$
f(y)=C \int E_{z} y d y+d \int E_{z} d y+e,
$$

where $\mathrm{C}, \mathrm{d}, \mathrm{e}-$ integration constants determined on the basis of conditions (3) and (4).

As a result of our problem solving, formulas for stresses calculation in the beam are as follows:

$$
\begin{aligned}
\sigma_{z} & =-\frac{6 P z}{h S} E_{z}(y)\left(2 S_{1} y-S_{2}\right) \\
\tau_{z y} & =\frac{6 P}{h S} \int_{0}^{y} E_{z}(y)\left(2 S_{1} y-S_{2}\right) d y
\end{aligned}
$$

where $S_{1}=\int_{0}^{b} E_{z} d y ; S_{2}=2 \int_{0}^{b} E_{z} y d y$;

$$
\mathrm{S}=12\left[\int_{0}^{\mathrm{b}} \mathrm{E}_{\mathrm{z}} \mathrm{dy} \cdot \int_{0}^{\mathrm{b}} \mathrm{E}_{\mathrm{z}} \mathrm{y}^{2} \mathrm{dy}-\left(\int_{0}^{\mathrm{b}} \mathrm{E}_{\mathrm{z}} \mathrm{ydy}\right)^{2}\right]
$$

The equation for the beam deflective axis is the same as for the isotropic beam with stiffness D equaling to

$$
\begin{gathered}
\mathrm{D}=\frac{\mathrm{hS}}{12 \mathrm{~S}_{1}} \\
\mathrm{y}=\frac{\mathrm{P}}{6 \mathrm{D}}\left(\mathrm{z}^{3}-31^{2} \mathrm{z}+2 \mathrm{l}^{3}\right)
\end{gathered}
$$

Thus, considering this condition it is possible to calculate deflection of wood planks obtained by conventional sawing, $\mathrm{y}_{1}$, and sawing parallel to generatrix, $\mathrm{y}_{2}$, and use the relation, i.e.

$$
\frac{y_{1}}{y_{2}}=\frac{P\left(z^{3}-31^{2} z+21^{3}\right) 6 D_{2}}{6 D_{1} \cdot P\left(z^{3}-31^{2} z+21^{3}\right)}=\frac{D_{2}}{D_{1}}
$$

This relation will demonstrate what fold differs the stiffness of wood planks obtained as per two log cutup schemes.

\section{Conventional sawing method}

In this case the function of elasticity modulus $E_{z}$ may be represented by the following algebraic function:

$$
E_{z}=E_{z}^{0}+E_{z 1}(2 y-b)^{2}+E_{z 2}(2 y-b)^{4}
$$

where $\mathrm{E}_{\mathrm{z} 1}, \mathrm{E}_{\mathrm{z} 2}$ - coefficients of algebraic equation (13) determined by calculation;
$E_{z}^{0}-$ absolute term of the equation (13) representing the value of elasticity modulus in the beam layer for $y=\frac{b}{2}$.

The example of determination of the equation coefficients and the absolute term (13):

Following the calculation of change in elasticity modulus $E_{z}$ throughout the section height based on the previously derived complicated formula:

$$
\begin{aligned}
& \frac{1}{\mathrm{E}_{\mathrm{z}}}=\frac{\mathrm{n}_{3}{ }^{4}}{\mathrm{E}_{\mathrm{t}}}+\frac{\mathrm{1}_{3}{ }^{4}}{\mathrm{E}_{\mathrm{r}}}+\frac{\mathrm{m}_{3}{ }^{4}}{\mathrm{E}_{\mathrm{a}}}+\left(\frac{1}{\mathrm{G}_{\mathrm{ar}}}-\frac{2 \mu_{\mathrm{ar}}}{\mathrm{E}_{\mathrm{a}}}\right) \cdot \mathrm{m}_{3}{ }^{2} \mathrm{l}_{3}{ }^{2}+ \\
& +\left(\frac{1}{\mathrm{G}_{\mathrm{rt}}}-\frac{2 \mu_{\mathrm{rt}}}{\mathrm{E}_{\mathrm{t}}}\right) \cdot 1_{3}{ }^{2} \mathrm{n}_{3}{ }^{2}+\left(\frac{1}{\mathrm{G}_{\mathrm{at}}}-\frac{2 \mu_{\mathrm{at}}}{\mathrm{E}_{\mathrm{a}}}\right) \cdot \mathrm{m}_{3}{ }^{2} \mathrm{n}_{3}{ }^{2}
\end{aligned}
$$

(Glukhikh, Khrabrova, Akopyan, 2013), $\mathrm{E}_{\mathrm{z}}^{0}, \mathrm{E}_{\mathrm{zK}}, \mathrm{E}_{\mathrm{zc}}$ are known.

Using these values, it is possible to approximate elasticity modulus $\mathrm{E}_{\mathrm{z}}$ with algebraic function of the fourth order. For this purpose it is sufficient to find coefficients for variable $\mathrm{E}_{\mathrm{zK}}, \mathrm{E}_{\mathrm{zc}}$ using the following conditions:

- the edge: for $\mathrm{y}=0$, elasticity modulus $\mathrm{E}_{\mathrm{zK}}=\mathrm{E}_{\mathrm{zK}}^{\mathrm{p}}$, i.e. is equal to the calculated elasticity modulus $\mathrm{E}_{\mathrm{zK}}^{\mathrm{p}}$;

- passing point: for $y=\frac{b}{4}$, elasticity modulus $E_{z c}$ is equal to the calculated elasticity modulus $E_{z c}^{P}$;

- the beam middle: for $y=\frac{b}{2}$, elasticity modulus $\mathrm{E}_{\mathrm{z}}^{0}$ is equal to the calculated elasticity modulus $\mathrm{E}_{\mathrm{zp}}^{0}$.

\section{Sawing parallel to generatrix}

The function of elasticity modulus $\mathrm{E}_{z}$ may be represented by the following algebraic function:

$$
\mathrm{E}_{\mathrm{z}}=\mathrm{E}_{\mathrm{a}}-\mathrm{E}_{\mathrm{z} 1}(2 \mathrm{y}-\mathrm{b})^{2}-\mathrm{E}_{\mathrm{z} 2}(2 \mathrm{y}-\mathrm{b})^{4}
$$

where $\mathrm{E}_{\mathrm{a}}$ is absolute term of the equation (14) representing the value of elasticity modulus in the beam layer for $\mathrm{y}=\frac{\mathrm{b}}{2}$;

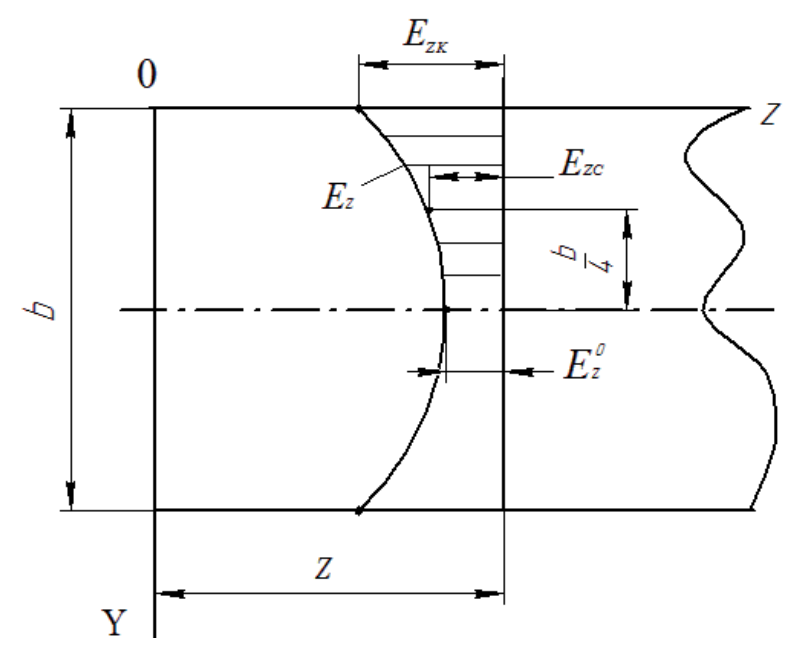

Fig.4 Change in elasticity modulus Ez across the wood plank width at conventional sawing 


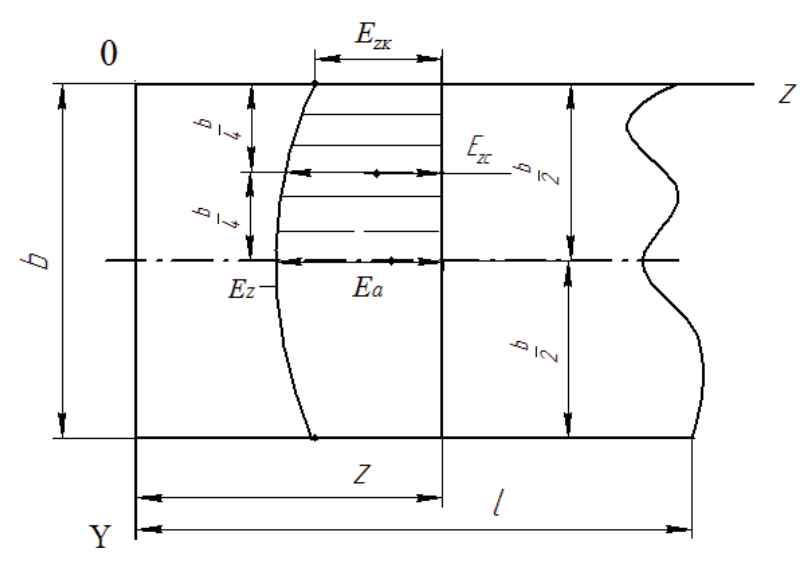

Fig.5 Change in elasticity modulus Ez across the wood plank width at sawing parallel to generatrix

$\mathrm{E}_{\mathrm{z} 1}, \mathrm{E}_{\mathrm{z} 2}$ - coefficients of algebraic equation (14) determined by calculation.

Thereby the following conditions are to be met: elasticity modulus in the neutral layer is $\mathrm{E}_{\mathrm{a}^{\prime}}$ and at the edges $-\mathrm{E}_{\mathrm{zk}}$. It is considered that for $\mathrm{y}=\frac{\mathrm{b}}{4}$, elasticity modulus is also known (the same as for the previous problem).

- for $y=0 \quad E_{z}=E_{z k}$, i.e. $E_{z k}=E_{a}-E_{z 1} b^{2}-E_{z 2} b^{4}$

$$
\begin{aligned}
\text { - for } \mathrm{y} & =\frac{\mathrm{b}}{2} \quad \mathrm{E}_{\mathrm{z}}=\mathrm{E}_{\mathrm{a}} \\
\text { - for } \mathrm{y}= & \frac{\mathrm{b}}{4} ; \quad \mathrm{E}_{\mathrm{z}}=\mathrm{E}_{\mathrm{zc}} \\
\mathrm{E}_{\mathrm{zc}}= & \mathrm{E}_{\mathrm{a}}-\mathrm{E}_{\mathrm{z} 1}\left(2 \frac{\mathrm{b}}{4}-\mathrm{b}\right)^{2}-\mathrm{E}_{\mathrm{z} 2}\left(2 \frac{\mathrm{b}}{4}-\mathrm{b}\right)^{4}= \\
& =\mathrm{E}_{\mathrm{a}}-\mathrm{E}_{\mathrm{z} 1} \frac{\mathrm{b}^{2}}{4}-\mathrm{E}_{\mathrm{z} 2} \frac{\mathrm{b}^{4}}{16}
\end{aligned}
$$

5. Results. Distribution of the elasticity modulus across the wood plank width

The diagrams above (Fig. 6) show the changes in elasticity modulus across the wood plank width when different sawing methods are used. For the first time it is determined that in case of sawing in parallel to generatrix maximum $\mathrm{E}_{\mathrm{z}}$ value is reached in the wood plank center and reduced when getting closer to the edges. In case of conventional sawing, reverse behavior may be seen.

When, in case of conventional sawing, a wood plank moves away from the log longitudinal axis, the elasticity modulus decreases. Vice versa, in case of sawing parallel to generatrix, the elasticity modulus increases.

When a wood plank is sawn out at a distance of $80 \mathrm{~mm}$ from the log longitudinal axis, the average elasticity modulus, in case of conventional sawing,
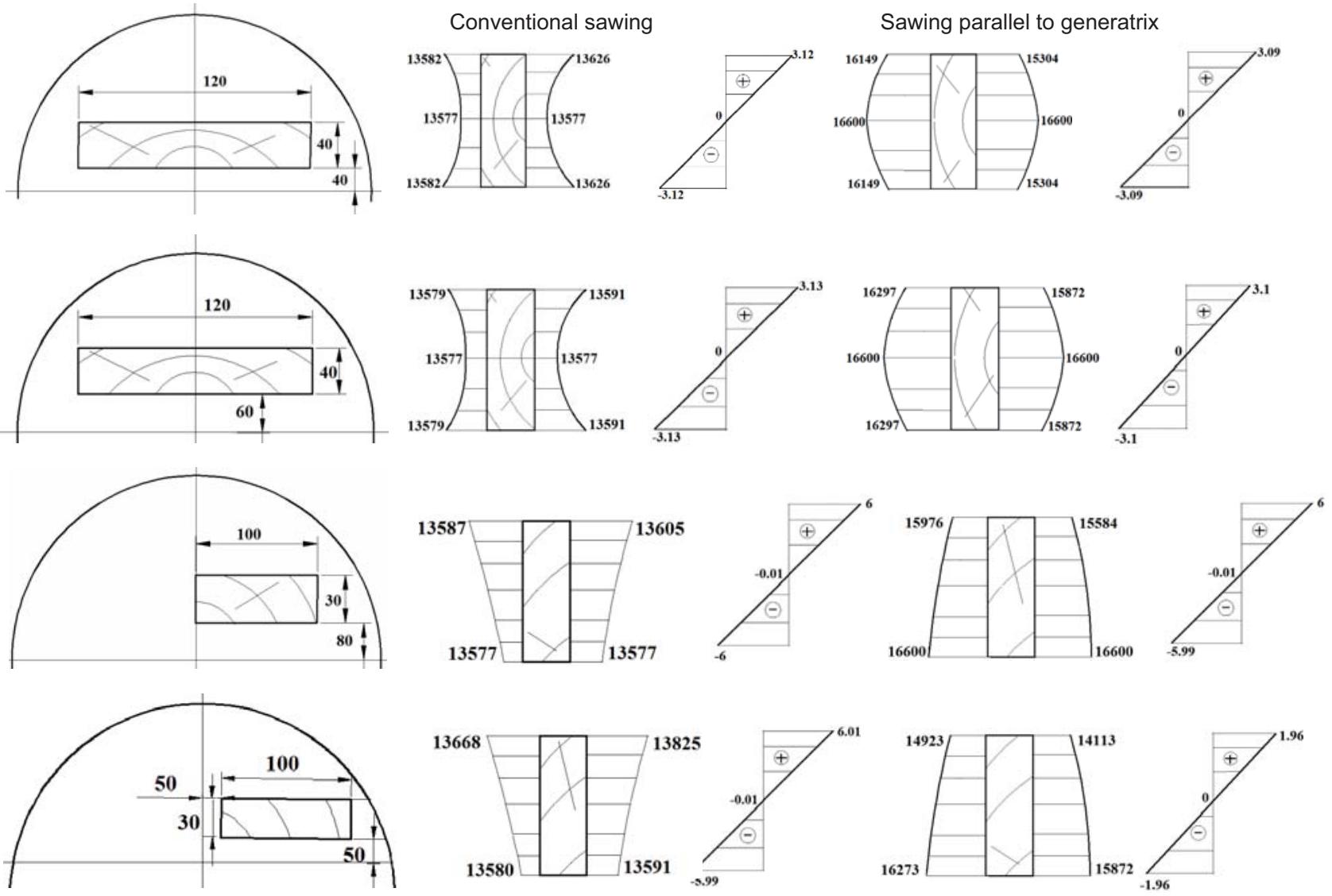

Fig. 6 Comparison of the elasticity modulus and stress sketches across the wood plank width. Conventional sawing and sawing parallel to generatrix. 
Table 1

Wood plank stiffness, various coordinates $\left(\gamma=3^{\circ}\right)$

\begin{tabular}{|c|c|c|c|c|c|}
\hline \multicolumn{2}{|c|}{$\begin{array}{l}\text { Coordinate of wood } \\
\text { plank sawn face } \\
\text { width, B mm }\end{array}$} & \multirow{3}{*}{$\begin{array}{l}\text { Distance from the log axis } \\
\text { to the sawn face under } \\
\text { investigation, b, } \mathrm{mm}\end{array}$} & \multirow{2}{*}{\multicolumn{2}{|c|}{ Stiffness }} & \multirow{3}{*}{$\begin{array}{l}\text { Wood } \\
\text { bending, } \\
D_{2} / D_{1}\end{array}$} \\
\hline $\mathrm{B}_{1}$ & $\mathrm{~B}_{2}$ & & & & \\
\hline & & & Conventional sawing, $D_{1}$ & $\begin{array}{c}\text { Sawing parallel to } \\
\text { generatrix, } D_{2}\end{array}$ & \\
\hline-60 & 60 & 40 & $7,833,468$ & $9,046,821$ & 1.15 \\
\hline-60 & 60 & 60 & $7,823,873$ & $9,291,571$ & 1.19 \\
\hline-60 & 60 & 80 & $7,821,558$ & $9,399,283$ & 1.2 \\
\hline-60 & 60 & 100 & $7,820,875$ & $9,454,118$ & 1.21 \\
\hline 50 & 150 & 50 & $3,423,186$ & $3,727,653$ & 1.08 \\
\hline 50 & 150 & 80 & $3,403,472$ & $3,898,885$ & 1.14 \\
\hline
\end{tabular}

equals to $E_{\text {avg }}=13580$; in case of sawing in parallel to tapering. The average elasticity modulus equals to $\mathrm{E}_{\text {avg }}=16487$. It turns out that the elasticity modulus is $19 \%$ higher when sawing parallel to tapering. For calculation purposes, the angle of generatrix tilting $\gamma$ to the log axis was taken as equal to 3 . If the angle equals 5 , the elasticity modulus is $46 \%$ higher when sawing parallel to generatrix.

Table 1 shows variation in stiffness of sawn wood products obtained from different sections of a log. In case of sawing parallel to generatrix, stiffness of a wood plank increases with increase in the distance from the log axis to the sawn face under investigation. In case of conventional sawing, stiffness, in reverse, decreases with increase in the distance. In terms of percentage ratio, stiffness of sawn wood products in case of sawing parallel to tapering $(\gamma=30)$ is $14-19 \%$ higher than that of sawn wood products obtained by conventional sawing. The obtained sawn wood products exhibit less deflection and higher strength properties.

\section{Summary}

The elasticity modulus describes material properties in terms of higher or lower deformation under load. Stiffness of materials limited by elasticity may be compared using the value of elasticity modulus.

Mathematical models describing changes in elasticity modulus of a wood plank width sawn parallel to generatrix enable to foresee the wood plank bending strength and stiffness.

The suggested procedure allows for the evaluation of bending stresses of wood planks obtained by various log cut-up schemes.

Sawn wood products obtained by sawing parallel to generatrix exhibit higher strength and stiffness properties which can be used in fabrication of construction part and structures with improved strength properties.

The investigation results are not only of scientific interest, but also of practical one in terms of construction and fabrication of laminated wood structures, wood structural panels, etc.

\section{References}

Akishenkov S. I. (1980) O pokazatelyakh kachestva sushki pilomaterialov. [On sawn wood products drying quality]. Aktual'nye napravleniya razvitiya sushki drevesiny: Tezisy dokladov Vsesoyuznoj konferentsii. TSNIIMOD [Current approaches to wood drying development: All-Soviet Union conference abstracts. Central Scientific-Research Institute of Wood Machining], Arkhangelsk, p. 100-101. (In Russian)

Ashkenazi E. K. (1978) Anizotropiya drevesiny i drevesnykh materialov. [Anisotropy of wood and wood materials]. Forest industry, Moscow. (In Russian)

Glukhikh V. N. (2007) Anizotropiya drevesiny kak faktor dlya povysheniya kachestva sushki pilomaterialov. [Anisotropy of wood as a driver of sawn wood products drying improvement]. Publishing office of St. Petersburg University. Saint Petersburg. (In Russian)

Glukhikh V. N. (2004) Napryazheniya v tsilindricheski anizotropnoy polose, nagruzhennoy poperechnoy siloy na kontsakh. [Stresses in cylindrical anisotropy strip under transverse loading force at the ends]. Izvestiya SPbLTA [News of Saint Petersburg Forest Engineering Academy], Issue 171. Forest Engineering Academy, Saint Petersburg, pp. 158-165.

Glukhikh V. N., Zaripov Sh. G. (2008) Poperechnoe koroblenie pilomaterialov pri sushke. [Transverse distortion of sawn wood products at drying]. Izvestiya SPbLTA [News of Saint Petersburg Forest Engineering Academy], Issue 181. Forest Engineering Academy, Saint Petersburg, pp. 179-186. (In Russian) 
Glukhikh V. N., Khrabrova O. Yu, Akopyan A. L (2013) Postoyannye uprugosti pilomaterialov pri raspilovke breven parallel'no obrazuyushchey. [Constant elasticity of sawn wood materials at sawing of logs in direction parallel to generatrix]. Izvestiya SPbLTA [News of Saint Petersburg Forest Engineering Academy], Issue 203. Forest Engineering Academy, Saint Petersburg, pp. 117-127. (In Russian)

Glukhikh V. N., ChernykhA. G. (2013)Anizotropiya drevesiny. Tekhnologicheskiy aspect. [Anisotropy of wood. Processing aspect]. Saint Petersburg State University of Architecture and Civil Engineering, Saint Petersburg. (In Russian)

Kolenchuk K. I. (1950) Poperechnoe koroblenie drevesiny. [Wood transverse distortion]. Sbornik trudov instituta stroitel'noi mekhaniki AN USSR [Collection of paperworks, Institute of Structural Mechanics of Academy of Sciences of the Ukrainian SSR], \# 12. (In Russian)

Lekhnitskiy S. G. (1957) Anizotropnye plastinki. [Anisotropic plates]. Gostechizdat, Moscow.

Lyulenko V. N. (1967) Issledovanie vliyaniya nekotorykh faktorov na velichinu koroblenniya. [Investigation of some drivers effect over distortion value]. Ph.D. thesis, Leningrad. (In Russian)

Petrukhin G. G. (1970) Koroblenie pilomaterialov pri mekhanicheskoy obrabotke. [ Sawn wood products machining distortion]. Sb. rabot: MLTI [Collection of papers: Moscow Forest Engineering Institute]. \# 35. (In Russian)

Petrukhin G. G. (1970) Koroblenie poperechnykh secheniy derevyannykh elementov. [Distortion of wooden elements cross sections]. Sb. rabot: MLTI [Collection of papers: Moscow Forest Engineering Institute]. \# 35. (In Russian)

Skripal'shchikova N. F. (1975) Issledovaniya i metod snizheniya korobleniya pilomaterialov vo vremya kamernoy sushki. [Investigations and method of sawn wood products distortion decrease at kiln drying]. Sushka drevesiny: Materialy Vsesoyuznogo nauchno-tekhnicheskogo soveshchaniya [Wood drying: Paperwork of All-Soviet Union Scientific and Research Meeting]. Central Scientific-Research Institute of Wood Machining, Arkhangelsk. (In Russian)

Sokolov P. V, Glukhikh V. N (1971) Vliyanie nekotorykh faktorov na silu korobleniya drevesiny. [Effect of some drivers on wood distortion forces]. Derevoobrabatyvayushchaya promyshlennost' [Wood-working industry]. \# 3. (In Russian)

Strikha I. A. (1974) Prichina deformatsiy detaley iz drevesiny i sposoby ee umen'sheniya. [Causes of wooden parts deformation and ways of its decrease]. Derevoobrabatyvayushchaya i lesokhimicheskaya promyshlennost' [Woodworking and wood chemical industry]. \# 7. (In Russian)

Sukhova A. V. (1958) K voprosu o poperechnykh korobleniyakh drevesiny. [On wood transverse distortion]. Khimki. (In Russian) 